Scientia Marina 77(1)

March 2013, 37-45, Barcelona (Spain)

ISSN: 0214-8358

doi: 10.3989/scimar.03698.26B

\title{
Salinity as the main factor structuring small-bodied fish assemblages in hydrologically altered Mediterranean coastal lagoons
}

\author{
SÍLVIA RODRÍGUEZ-CLIMENT, NUNO CAIOLA and CARLES IBÁÑEZ \\ IRTA Aquatic Ecosystems, E-43540 Sant Carles de la Ràpita, Catalonia, Spain. E-mail: nuno.caiola@irta.cat
}

\begin{abstract}
SUMMARY: In the Ebro Delta coastal lagoons, one of the main anthropogenic pressures is the artificial freshwater input. Each coastal lagoon has different water management schemes causing profound changes in its physicochemical characteristics. The main objective of this water management is to favour some bird species with interest either for conservation or hunting activities. The present study assesses the influence of hydrological alteration on the fish assemblages of three coastal lagoons in the Ebro Delta. The small-bodied fish fauna was mainly composed of five families: Gobiidae, Poecilidae, Cyprinodontidae, Atherinidae and Mugilidae. Salinity was found to be the main factor structuring fish community in the lagoons. The dominant species was the common goby (Pomatochistus microps) when the lagoons reached higher salinity values, whereas the invasive eastern mosquitofish (Gambusia holbrooki) dominated during the period of higher freshwater inputs. The juveniles of the family Mugilidae showed low catch per unit effort, especially during the period of lower salinity. This same pattern was found for the endangered Spanish toothcarp (Aphanius iberus). Overall, introduced species were favoured by low salinity, which highlights the importance of changing the present water management by reducing the freshwater inputs in order to maintain suitable levels of salinity to favour native species that are important for both commercial and conservation purposes.
\end{abstract}

Keywords: fish community, salinity, water management, Ebro Delta, coastal lagoons.

RESUMEN: LA SALINIDAD COMO EL PRINCIPAL FACTOR EN LA ESTRUCTURACIÓN DE COMUNIDADES DE PECES DE PEQUEÑO TAMAÑO EN LAGUNAS COSTERAS MEDITERRÁNEAS HIDROLÓGICAMENTE ALTERADAS. - Una de las mayores presiones antropogénicas sobre las lagunas costeras del Delta del Ebro es la entrada artificial de agua dulce. Cada laguna costera presenta medidas de gestión distintas que alteran profundamente sus propiedades fisicoquímicas. Esta gestión del agua tiene como objetivo favorecer algunas especies de aves con interés para la caza y/o conservación. El presente estudio evalúa la influencia de la alteración hidrológica en la comunidad de peces de tres lagunas costeras del Delta del Ebro. La fracción de la ictiofauna integrada por individuos de pequeño tamaño estaba mayormente compuesta por cinco familias: Gobiidae, Poecilidae, Cyprinodontidae, Atherinidae y Mugilidae. La salinidad fue el factor que más contribuyó a la estructuración de la comunidad de peces de las lagunas. Con valores máximos de salinidad, la especie dominante en las lagunas fue el Gobito (Pomatoschistus microps), mientras que la Gambusia (Gambusia holbrooki), una especie invasora, fue dominante durante el período con mayores aportes de agua dulce. Los juveniles de la familia Mugilidae presentaron valores bajos de Capturas por Unidad de Esfuerzo (CPUE), especialmente durante el período de menor salinidad. El mismo patrón fue encontrado para el Fartet (Aphanius iberus), especie en peligro de extinción. En general, las especies introducidas fueron favorecidas por una baja salinidad, hecho que subraya la importancia de modificar la presente gestión del agua reduciendo los aportes de agua dulce con el fin de mantener niveles adecuados de salinidad que favorezcan a las especies nativas, importantes tanto desde el punto de vista comercial cómo conservacionista.

Palabras clave: comunidad de peces, salinidad, gestión del agua, Delta del Ebro, lagunas costeras.

\section{INTRODUCTION}

Coastal lagoons are located at the land-sea interface and are generally characterized by high biological productivity and shallowness (Barnes 1980, Brehmer et al. 2011). They are used by many fish species either as feeding, nursery or spawning grounds (PérezRuzafa et al. 2004, Oertli et al. 2005, Ribeiro et al. 
2006, Verdiell-Cubedo 2009). Usually dominated by marine and estuarine species, coastal lagoon fish assemblages may have different compositions and structures, depending mainly on the balance between marine and freshwater inputs (Gordo and Cabral 2001). The Mediterranean coastal lagoons are highly modified ecosystems due to the impacts of human activities such as intensive agriculture, urban and industrial land uses, canal construction and impoundments, dredging and tourism. These activities cause serious changes in the natural ecological cycles, particularly water regime alterations caused by artificial freshwater inputs (Pérez-Ruzafa et al. 1991, Day et al. 2000, Caiola et al. 2001a, b, Cañedo-Argüelles et al. 2012, VerdiellCubedo 2009). The most common consequences of these hydrological alterations are the decline in salinity and the increase in both eutrophication and environmental pollution as a result of increased nutrient and chemical contaminant inputs (Cloern 2001, Lucena et al. 2002, Cañedo-Argüelles et al. 2012). Despite the severe impacts that these hydrological alterations can have on the fish communities, studies focusing on this issue in the Mediterranean area are scarce (Poizat et al. 2004, Badosa et al. 2007).

Situated in Catalonia (north-east Spain), the Ebro Delta, covering an area of $320 \mathrm{~km}^{2}$, is one of the most important estuarine systems in Europe. Due to the high ecological interest, $25 \%$ of its area, including the coastal lagoons, bays and adjacent coastline, has been protected as a natural park since 1983. The natural park conservation status means that the protection of the natural areas must be compatible with the use of their resources and the activities of their inhabitants, such as fisheries, hunting and agriculture. The rest of the area is used for agriculture, mainly rice cultivation (Day et al. 2006). To sustain this agricultural activity two main canals, regulated at their source $(40 \mathrm{~km}$ upstream of the river mouth), are split into numerous secondary canals and ditches to bring freshwater to all rice fields in the delta. Freshwater supply is only interrupted between January and April to prepare the fields for the next crop. In the past, waste water from the rice fields was drained to the lagoons, and from these systems to the sea through the outlets. This water management scheme caused eutrophication in the coastal lagoons, a problem that was overcome in the 1990s with the construction of circumvallation canals that prevent drainage water from passing through the lagoons (Forés et al. 2002). At present the Ebro Delta coastal lagoons still receive freshwater artificially, mainly for habitat management to favour game birds. The freshwater comes both from the river, through the irrigation canals, and from the rice field drainage. The quality of the river water has increased significantly in the last 15 years (Nebra et al. 2011, Ibánez et al. 2012a,b) and the water input from rice field drainage is only opened in periods of low pesticide and fertilizer input (Forés et al. 2002). As a result, water quality in the lagoons has improved, but

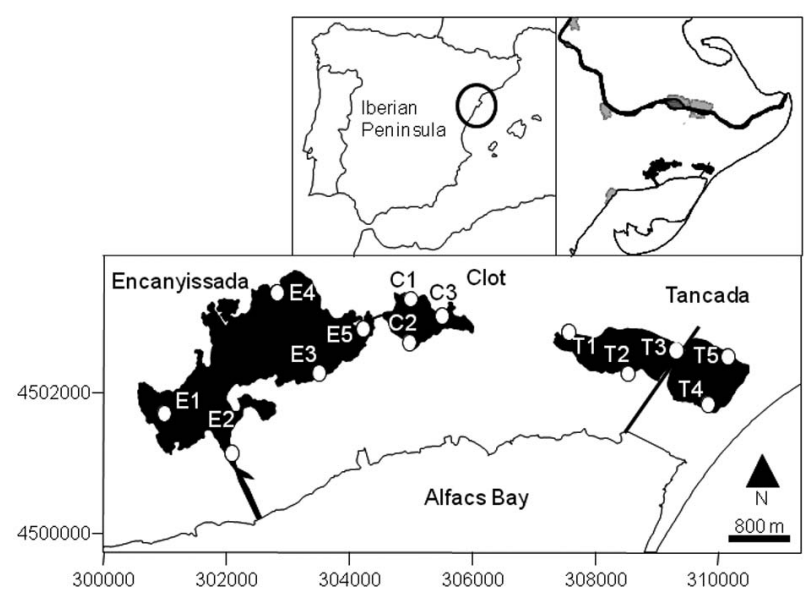

FIG. 1. - Map showing the location of the Ebro Delta and the sampled coastal lagoons. White spots represent sampling sites.

their hydrology is still severely altered. The effects of water management on the coastal lagoons' fish assemblages remain unknown. The approach of sampling small-sized resident fish species and juveniles of migratory species was chosen because the capacity of movement of larger species and the adults of migratory species make them unreliable as descriptors of spatial distribution (Mariani, 2001). Moreover, if only small-bodied fishes are analysed, target species are not taken into account, so the effect of fisheries on the fish community is excluded.

The present study aims to describe the composition of small-bodied fish assemblages from the Ebro Delta coastal lagoons and to investigate the relationship between assemblage structure and distribution patterns and the main environmental features that depend on artificial water management. The degree of association of each species with the studied physicochemical parameters is also assessed.

\section{MATERIALS AND METHODS}

\section{Study area}

Three coastal lagoons located in the Ebro Delta were selected for this study: Encanyissada, Clot and Tancada (Fig. 1). The Encanyissada, with an area of $4.18 \mathrm{~km}^{2}$, is the largest lagoon in the delta; it has a mean depth of $77 \mathrm{~cm}(121 \mathrm{~cm}$ maximum depth) and a salinity ranging between 2 and 36. It is connected naturally to the Alfacs Bay (Mediterranean Sea) by the Sant Pere outlet (see Fig. 1) and to the Clot lagoon by a floodgate. The Clot is a small $\left(0.56 \mathrm{~km}^{2}\right)$ and shallow lagoon, with a mean depth of about $53 \mathrm{~cm}$ (maximum depth around $90 \mathrm{~cm}$ ) and a salinity ranging between 1 and 29. Closest to the sea, the Tancada lagoon has a surface area of $1.85 \mathrm{~km}^{2}$, a mean depth of $58 \mathrm{~cm}(80$ $\mathrm{cm}$ maximum depth) and a salinity ranging between 8 and 37. It is connected to the Alfacs Bay by several artificial canals (Fig. 1). 


\section{Sampling procedures}

Two sampling periods were selected, March and September 2008, coinciding with the periods of minimum and maximum artificial freshwater inputs, respectively. Fish were collected with fyke nets, a passive fishing gear that is increasingly used for scientific surveys (Poole et al. 2007), particularly for surveying small-bodied fish (Brazner et al.1998, Pampoulie et al. 2001, Uzarski et al. 2005, Fredberg et al. 2009, Wedderburn et al. 2012). The fyke nets used were $2 \mathrm{~m}$ long with a hoop diameter of $80 \mathrm{~cm}$ and mesh size of 5.0 $\mathrm{mm}$. A total of 26 fishing sets were settled in 13 different sampling locations so as to cover the maximum spatial gradient in each lagoon (5 in the Encanyissada and Tancada lagoons, 3 in the Clot lagoon) (Fig. 1). As coastal lagoons are shallow water bodies with a quite constant depth, and therefore aquatic habitat conditions, the fyke nets were set in the littoral zone where there is a higher probability of capturing fish due to habitat characteristics (higher macrophyte coverage and presence of helophytic and littoral vegetation). In fact, this same procedure is performed by local fishermen. Moreover, setting the fyke nets in the littoral zone allowed a constant depth of approximately $80 \mathrm{~cm}$ to be maintained between all the sampling points, corresponding to the fyke nets' hoop diameter (the whole water column was sampled for small-bodied fish). All nets were set in late afternoon and hauled the next morning, so average soak time was 12 hours. The fish were sorted, identified at species level and counted. This procedure complied with the fish specimen capture requirements as stated in the scientific capture permit issued by the Catalan Government: eliminating exotic species according to the current law (in this case with excess of anaesthetic MS-222) and releasing the native species after handling them. Each sampling site was also sampled for environmental descriptors that are directly affected by the water management. These descriptors are related to water physicochemical parameters, water nutrient loading variables, and water level expressed as depth $(\mathrm{cm})$. With regard to the physicochemical parameters, dissolved oxygen $\left(\mathrm{mgL}^{-1}\right)$, temperature $\left({ }^{\circ} \mathrm{C}\right)$, salinity and $\mathrm{pH}$ were measured with an YSI 556 multi-parameter probe. To determine the water nutrient loading water samples were collected, preserved on ice in the absence of light, transported to the laboratory and stored at $-20^{\circ} \mathrm{C}$ until a dissolved nutrient concentration analysis was done. The nutrients analyzed were ammonium (N$\left.\mathrm{NH}_{4}\right)$, nitrite $\left(\mathrm{N}-\mathrm{NO}_{2}\right)$, nitrate $\left(\mathrm{N}-\mathrm{NO}_{3}\right)$ and phosphate $\left(\mathrm{P}-\mathrm{PO}_{4}\right)$, following Koroleff (1977).

\section{Statistical analysis}

Fish abundance was expressed as catch per unit effort (CPUE), an index of relative abundance that represents the success of capture. CPUE values were calculated as number of captured fish per fishing set. Fishing time was assumed to be equal, since soaking time was roughly constant. Rare species (CPUE $<0.833$ and/or present at just one sampling site) were excluded from the analyses. Normality and homogeneity of variances of all physicochemical variables were tested with the Shapiro-Wilk test and the Levene statistic (Clifford and Taylor 2008). Physicochemical variables were log-transformed and species data were square-root transformed when necessary in order to improve linearity and normality of variances (Quinn and Keough 2002). Analysis of variance (ANOVA) was used to compare physicochemical descriptors between lagoons and sampling periods, followed by Games-Howell post-hoc test (GH test). A Canonical Correspondence analysis (CCA) was performed in order to extract the species variation explainable by the measured physicochemical parameters (Lepš and Šmilauer 2003). To describe the individual species response to salinity, generalized additive models (GAMs) were fitted assuming a Poisson distribution and a log link function. GAMs are an extension of the general lineal models that do not require the assumption of a linear relationship between environmental variables and the species distribution (Hastie and Tibshirani 1986, Lepš and Šmilauer 2003). The model complexity of GAMs was selected by the stepwise selection procedure using the Akaike Information Criterion (AIC), which considers not only goodness of fit but also parsimony, penalizing very complex models (Lepš and Śmilauer 2003). Thus, the relationship between the predictors and the dependent variable can assume any shape, from a straight line to non-parametric curves of increasing complexity (Alcaraz et al. 2011). Tolerance ranges of the species were analyzed by data attribute plots with salinity as the environmental variable. The statistical analyses were performed with SPSS 17.0 and CANOCO 4.5.

\section{RESULTS}

\section{Environmental descriptors}

The environmental descriptors of the three lagoons were compared between the two sampled periods (Table 1). Significant differences were found in temperature $\left(F_{1,92}=95.57 ; p<0.01\right)$, depth $\left(F_{1,92}=47.63 ; p<0.01\right)$, $\mathrm{pH}\left(F_{1,92}=19.15 ; p<0.01\right)$ and salinity $\left(F_{1,94}=100.33\right.$; $p<0.01$ ), whereas no differences were found in oxygen concentration $\left(F_{1,91}=0.22 ; p=0.64\right)$. The mean temperature in March was significantly lower than in September $(G H, p<0.01)$; Tancada lagoon was the coldest and Clot lagoon the warmest $(G H, p<0.01)$. All three lagoons showed significantly higher mean depth values in September, with Encanyissada lagoon being the deepest $(G H, p<0.01)$. The $\mathrm{pH}$ was highest in September, being statistically significant only for the Clot $(G H, p<0.05)$ and Tancada lagoons $(G H$, $p<0.01$ ). Tancada lagoon showed the lowest $\mathrm{pH}$ values. In contrast, the salinity was significantly higher in March than in September $(G H, p<0.01)$. The maximum observed salinity was in the Tancada lagoon in March 
TABLE 1. - Environmental descriptors for the three lagoons in the two sampled periods. Mean \pm standard deviation is shown. DO, dissolved oxygen. * statistical significance between seasons. ** statistical significance between lagoons. ns, non-significant differences.

\begin{tabular}{|c|c|c|c|c|c|c|c|c|c|c|c|c|c|}
\hline & & Clot & & $\begin{array}{c}\text { March } 2008 \\
\text { Encanyissada }\end{array}$ & & Tancada & & Clot & & $\begin{array}{l}\text { September } 200 \\
\text { Encanyissada }\end{array}$ & & Tancada & \\
\hline $\mathrm{T}\left({ }^{\circ} \mathrm{C}\right)$ & $*$ & $19.74 \pm 0.63$ & $* *$ & $16.97 \pm 0.99$ & $* *$ & $11.87 \pm 0.34$ & $* *$ & $21.52 \pm 0.47$ & $* *$ & $20.15 \pm 1.31$ & $* *$ & $19.78 \pm 0.96$ & $* *$ \\
\hline $\mathrm{DO}\left(\mathrm{mg} \mathrm{l}^{-1}\right)$ & $n s$ & $8.28 \pm 0.82$ & & $7.96 \pm 1.12$ & & $8.30 \pm 1.17$ & & $7.93 \pm 0.84$ & & $8.00 \pm 1.18$ & & $7.95 \pm 0.76$ & \\
\hline Salinity & $*$ & $9.99 \pm 1.01$ & ** & $18.40 \pm 4.91$ & $* *$ & $30.30 \pm 0.89$ & $* *$ & $1.20 \pm 0.16$ & $* *$ & $9.04 \pm 2.00$ & $* *$ & $10.29 \pm 1.78$ & $* *$ \\
\hline $\mathrm{pH}$ & * & $7.93 \pm 0.07$ & ** & $8.11 \pm 0.16$ & $n s$ & $7.72 \pm 0.09$ & $* *$ & $8.23 \pm 0.18$ & $* *$ & $8.10 \pm 0.11$ & $n s$ & $8.21 \pm 0.18$ & $* *$ \\
\hline $\mathrm{P}-\mathrm{PO}_{4}\left(\mathrm{mg} \mathrm{l}^{-1}\right)$ & * & $>0.001$ & $* *$ & $0.012 \pm 0.004$ & $* *$ & $0.006 \pm 0.003$ & $* *$ & $0.045 \pm 0.022$ & $* *$ & $0.039 \pm 0.011$ & $* *$ & $0.040 \pm 0.011$ & $* *$ \\
\hline $\mathrm{N}-\mathrm{NH}_{4}\left(\mathrm{mg} \mathrm{l}^{-1}\right)$ & $n s$ & $0.003 \pm 0.003$ & & $0.037 \pm 0.023$ & & $0,156 \pm 0.176$ & & $0.055 \pm 0.092$ & & $0.100 \pm 0.071$ & & $0.194 \pm 0.059$ & \\
\hline $\mathrm{N}-\mathrm{NO}_{2}\left(\mathrm{mg} \mathrm{l}^{-1}\right)$ & $*$ & $0.003 \pm 0.000$ & $n s$ & $0.006 \pm 0.003$ & $n s$ & $0.008 \pm 0.003$ & $* *$ & $0.021 \pm 0.019$ & $n s$ & $0.007 \pm 0.002$ & $n s$ & $0.085 \pm 0.035$ & ** \\
\hline $\mathrm{N}-\mathrm{NO}_{3}\left(\mathrm{mg} \mathrm{l}^{-1}\right)$ & $n s$ & $0.010 \pm 0.006$ & & $0.157 \pm 0.165$ & & $0.075 \pm 0.077$ & & $0.191 \pm 0.320$ & & $0.023 \pm 0.044$ & & $0.374 \pm 0.265$ & \\
\hline Depth $(\mathrm{cm})$ & $*$ & $39.29 \pm 11.67$ & $* *$ & $65.07 \pm 15.23$ & ** & $56.50 \pm 10.31$ & $* *$ & $68.43 \pm 7.57$ & $* *$ & $91.30 \pm 17.35$ & $* *$ & $67.50 \pm 11.63$ & $* *$ \\
\hline
\end{tabular}

TABLE 2. - List of species captured in the Ebro Delta lagoons and its abundance in CPUE. Lagoon: C, Clot; E, Encanyissada; T, Tancada. Status: N, native; I, introduced. Species with codes in bold were selected for the analysis.

\begin{tabular}{|c|c|c|c|c|c|c|c|c|c|c|}
\hline \multirow[t]{2}{*}{ Family } & \multirow[t]{2}{*}{ Common name } & \multirow[t]{2}{*}{ Species } & \multirow[t]{2}{*}{ Code } & \multirow[t]{2}{*}{ State } & \multicolumn{3}{|c|}{ March 2008} & \multicolumn{3}{|c|}{ September 2008} \\
\hline & & & & & $\mathrm{C}$ & E & $\mathrm{T}$ & $\mathrm{C}$ & & $\mathrm{T}$ \\
\hline Anguillidae & European eel & Anguilla anguilla & AAN & $\mathrm{N}$ & 0.167 & 0.083 & 0.250 & & 0.083 & 0.083 \\
\hline Atherinidae & Sand smelt & Atherina boyeri & ABO & $\mathrm{N}$ & 0.500 & 3.417 & 7.417 & 4.000 & 21.667 & 0.167 \\
\hline Cyprinidae & Carp & Cyprinus carpio & $\mathrm{CCA}$ & I & & & 0.083 & & & \\
\hline Cyprinidontidae & South European toothcarp & Aphanius fasciatus & AFA & I & & 0.083 & & & & \\
\hline Cyprinidontidae & Spanish toothcarp & Aphanius iberus & AIB & $\mathrm{N}$ & 3.167 & 36.083 & 15.333 & & 2.417 & 0.417 \\
\hline Gobiidae & Common goby & Pomatoschistus microps & PMI & $\mathrm{N}$ & 30.917 & 148.917 & 221.750 & 77.083 & 22.083 & 10.833 \\
\hline Mugilidae & Thicklip grey mullet & Chelon labrosus & CLA & $\mathrm{N}$ & & 3.083 & 1.583 & & 0.833 & 0.083 \\
\hline Mugilidae & Golden mullet & Liza aurata & LAU & $\mathrm{N}$ & & 0.167 & 6.167 & & 1.250 & \\
\hline Mugilidae & Thinlip grey mullet & Liza ramada & LRA & $\mathrm{N}$ & & & 4.083 & & & \\
\hline Mugilidae & Leaping mullet & Liza saliens & LSA & $\mathrm{N}$ & 0.333 & 0.167 & 17.333 & & 2.000 & 0.500 \\
\hline Mugilidae & Flathead mullet & Mugil cephalus & MCE & $\mathrm{N}$ & & & 0.833 & & & \\
\hline Poecilidae & Eastern mosquitofish & Gambusia holbrooki & GHO & I & 5.333 & 3.250 & 0.333 & 218.333 & 95.917 & 0.417 \\
\hline Syngnathidae & Black-striped pipefish & Syngnathus abaster & SAB & $\mathrm{N}$ & & 0.250 & 0.083 & & & \\
\hline
\end{tabular}

(30.30; $G H, p<0.01$ ), whereas the lowest salinity was in the Clot lagoon (9.99; $G H, p<0.01)$. In addition, temperature, depth and $\mathrm{pH}$ were negatively correlated with salinity $(r=-0.87, p<0.01 ; r=-0.37, p<0.01$ and $r=-0.58, p<0.01$, respectively).

Regarding the dissolved nutrient concentration (Table 1), significant differences in nitrite and phosphate were found between sampling periods $\left(F_{1,42}=8.21\right.$ and $F_{1,41}=102.54$, respectively $\left.p<0.01\right)$. Nitrite concentrations were significantly higher in September, Tancada lagoon being the one reaching the highest concentrations $(0.085 \pm 0.035)$. The phosphate was significantly higher in September $(G H, p<0.05)$, with Clot showing the highest values. A negative correlation was found between salinity and phosphate $(r=-0.53, p<0.01)$. Furthermore, although no differences were found in ammonium and nitrate $\left(F_{1,42}=2.92\right.$ and $F_{1,41}=1.09$, respectively; $p>0.09)$, their concentrations were higher in September, except for nitrate in Encanyissada.

\section{Fish assemblages}

Overall, 13 species belonging to eight different families were captured in the three lagoons during the two sampling periods (Table 2). The small-bodied fish composition in the lagoons was composed of three introduced species $(23.08 \%)$ and ten native species $(76.92 \%)$. Although the native species dominated in terms of richness in all lagoons and sampling seasons, in terms of abundance the introduced species Gambu- sia holbrooki was dominant in September (69\%). This pattern was observed in all the lagoons except in the Tancada, where the native species dominated in the two periods (Table 2). For further analysis, the rare species were excluded, so finally seven species belonging to five families were analyzed (Fig. 2).

The small-bodied fish community in March was dominated by Pomatoschistus microps, Aphanius iberus and Liza saliens. P. microps was present in all lagoons and sampling sites, whereas A. iberus was present at all sampling points, except $\mathrm{T} 2$ and T3. L. saliens was mostly present in saltier habitats, particularly in the Tancada lagoon (Fig. 2). The presence of L. aurata was low and it was always concentrated in the saltier environments. The invasive Gambusia holbrooki occurred in fresher areas (the Clot and Encanyissada lagoons). In March Chelon labrosus was found almost exclusively in sampling points with sea connections (the Encanyissada and Tancada lagoons).

In September the community was dominated by freshwater and brackish species such as G. holbrooki, $P$. microps and Atherina boyeri. In this period, P. microps was dominant in the Tancada lagoon, whereas $G$. holbrooki was dominant in both the Clot and Encanyissada lagoons. The species $A$. boyeri was abundant in the Encanyissada lagoon. The endangered A. iberus was present in all lagoons except Clot. The mugilids L. saliens and C. labrosus were present in the saltier habitats (Tancada lagoon), whereas the presence of $L$. aurata was restricted to the Encanyissada lagoon. 


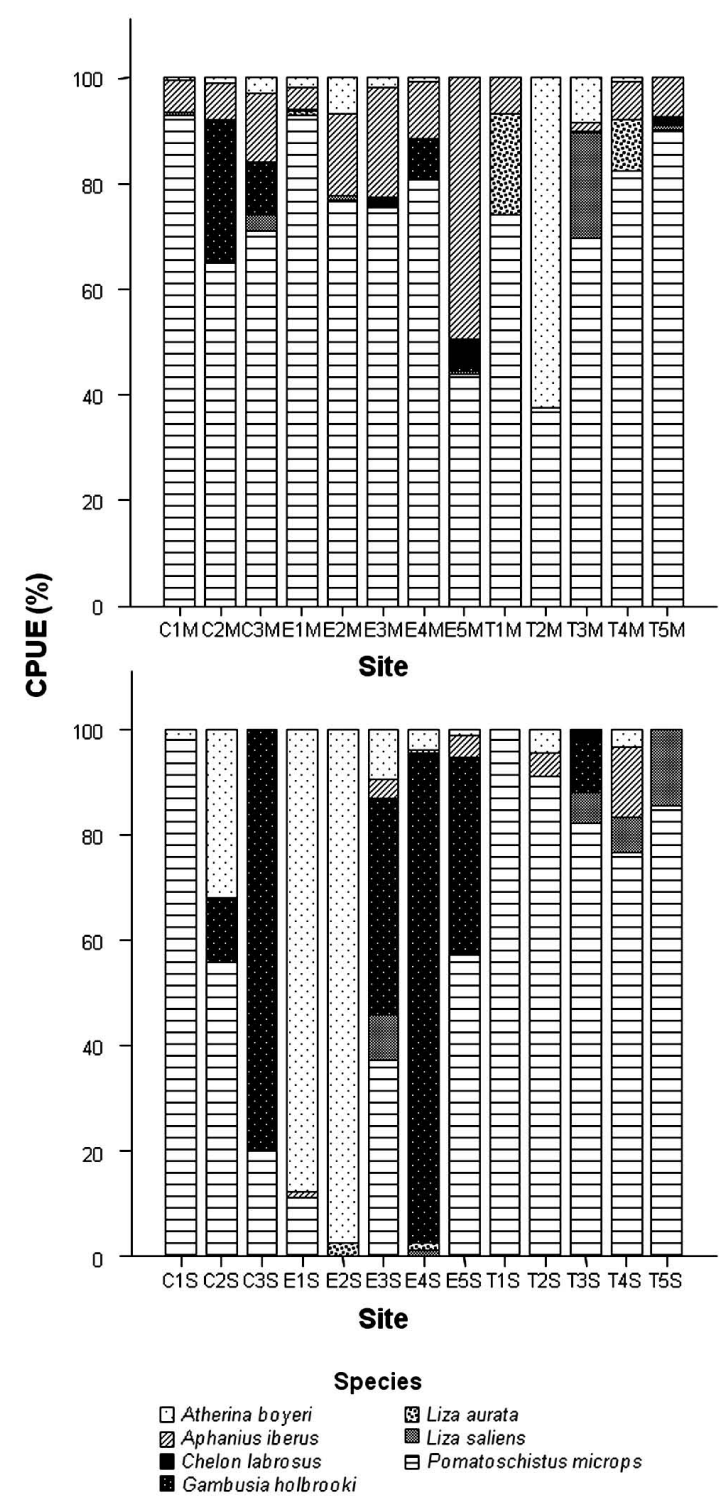

FIG. 2. - Percentage contribution of species to the overall abundance in the three lagoons sampled in March (above) and September (below). See Figure 1 for sampling site codes.

\section{Effects of environmental descriptors on the fish assemblages}

The first two axes of the CCA accounted for $27.4 \%$ of the total variability of the species data. The CCA summary statistics resulted in a significant first axis species-environment relationship $(r=0.836, p<0.01)$. Salinity $(F=5.17, \mathrm{p}<0.01)$ and depth $(F=2.42 ; p<0.05)$ were the only significant variables in the CCA analysis (Fig. 3). The first axis suggested a salinity gradient derived from the differences in the artificial freshwater inputs, which split September samples (fresher and deeper) from March samples (shallower and saltier). Regarding the species scores, brackish species such as Aphanius iberus, Pomatoschistus microps, Liza saliens, Liza aurata and Chelon labrosus, showed negative

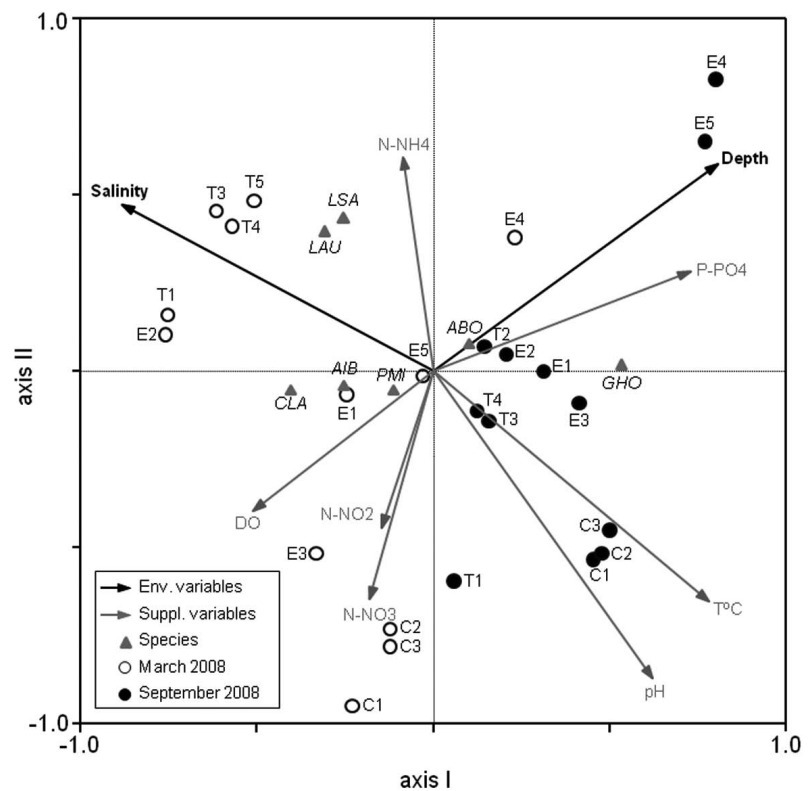

FIG. 3. - Correspondence canonical analysis triplot showing the relationships between physicochemical parameters, sampling sites and species. Significant and non-significant (supplementary) physicochemical parameters are plotted. Species abbreviations: ABO (Atherina boyeri), AIB (Aphanius iberus), CLA (Chelon labrosus), GHO (Gambusia holbrooki), LAU (Liza aurata), LSA (Liza saliens) and PMI (Pomatoschistus microps). See Figure 1 for sampling codes.

coordinate values, i.e. associated with higher salinity, whereas species with freshwater origin as G. holbrooki were situated in positive coordinates. Atherina boyeri was positioned near the centre of the plot. The samples ordination in the second axis $(4.1 \%$ of the total variability) indicated nitrogen loading with positive coordinate values for the ammonium and negative values for nitrate and nitrite. Then, high ammonium concentration samples were situated in the upper part of the plot (Tancada in March) and low ammonium loaded samples in the lower part (Clot in March).

\section{Species response to salinity}

The response curves of species abundances (expressed as CPUE square-root transformed) to salinity are shown in Figure 4. The significance of the response curves is shown in Table 3.

TABLE 3. - Results of the generalized additive models (GAM) applied to all the selected species, showing the explained deviance of the fitted model (Deviance), the residual degrees of freedom (DF residual) the Akaike information criterion (AIC), and the model significance (F value). Asterisks denote significance levels: $* * \mathrm{p}<0.01$; $* \mathrm{p}<0.05$.

\begin{tabular}{lrrrr}
\hline Species & Deviance & DF residual & AIC & \multicolumn{1}{c}{$\mathrm{F}$} \\
\hline Pomatoschistus microps & 127.55 & 21 & 161.66 & 3.83 \\
Gambusia holbrooki & 230.58 & 22 & 278.27 & $12.18 * *$ \\
Aphanius iberus & 70.87 & 21 & 87.36 & $10.73 * *$ \\
Liza saliens & 63.54 & 21 & 86.00 & 4.83 \\
Liza aurata & 44.99 & 22 & 62.37 & $4.06 *$ \\
Chelon labrosus & 28.40 & 21 & 37.75 & $6.02 * *$ \\
\hline
\end{tabular}



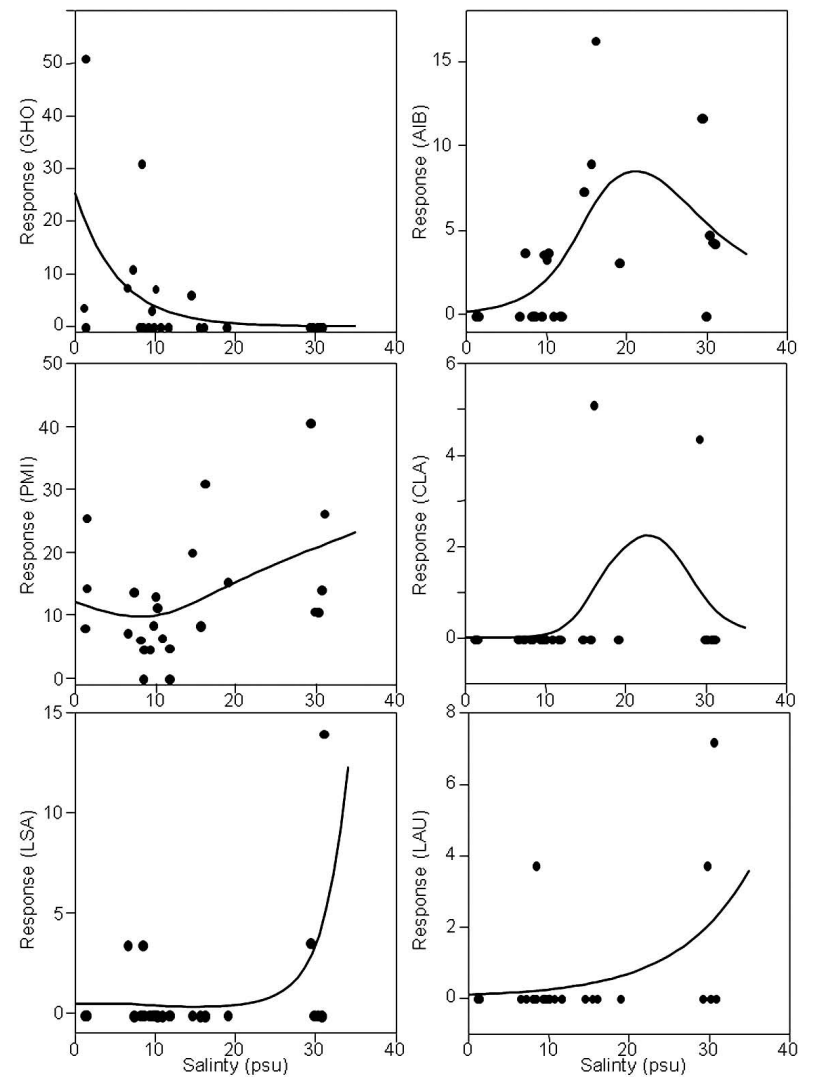

FIG. 4. - Response curves of species abundance (species selected by the model) to salinity. The curves are the generalized additive models (GAM) selected by the Akaike information criterion (AIC). Dots represent sampling sites. See Fig. 3 for species abbreviations.

Gambusia holbrooki decreased drastically with salinity, whereas Pomatoschistus microps increased with salinity values higher than 20 . The mugilids Liza saliens and Liza aurata increased constantly with salinity, whereas the endangered Aphanius iberus showed salinity preferences around 20. Chelon labrosus and Atherina boyeri were not plotted as they were not selected during the GAM iterative process. The salinity range for each species is shown in Figure 5. G. holbrooki has its optimum in freshwater environments, whereas A. boyeri is more adapted to mesohaline waters (around 15). The rest of the species have their optimums in brackish to marine waters (18-30).

\section{DISCUSSION}

The continuous freshwater inputs during nine months per year have inverted the hydrological pattern in the Ebro Delta coastal lagoons (De Sostoa and De Sostoa 1985, Comín et al. 1987). The inverted pattern was further confirmed in the present study by the opposite salinity cycle, since lagoons were found to have fresher water during dry seasons, when the lowest rainfall took place (Badosa et al. 2007). September was not only the month with the lowest salinity in the lagoons, but also the period with the highest $\mathrm{pH}$ values. These

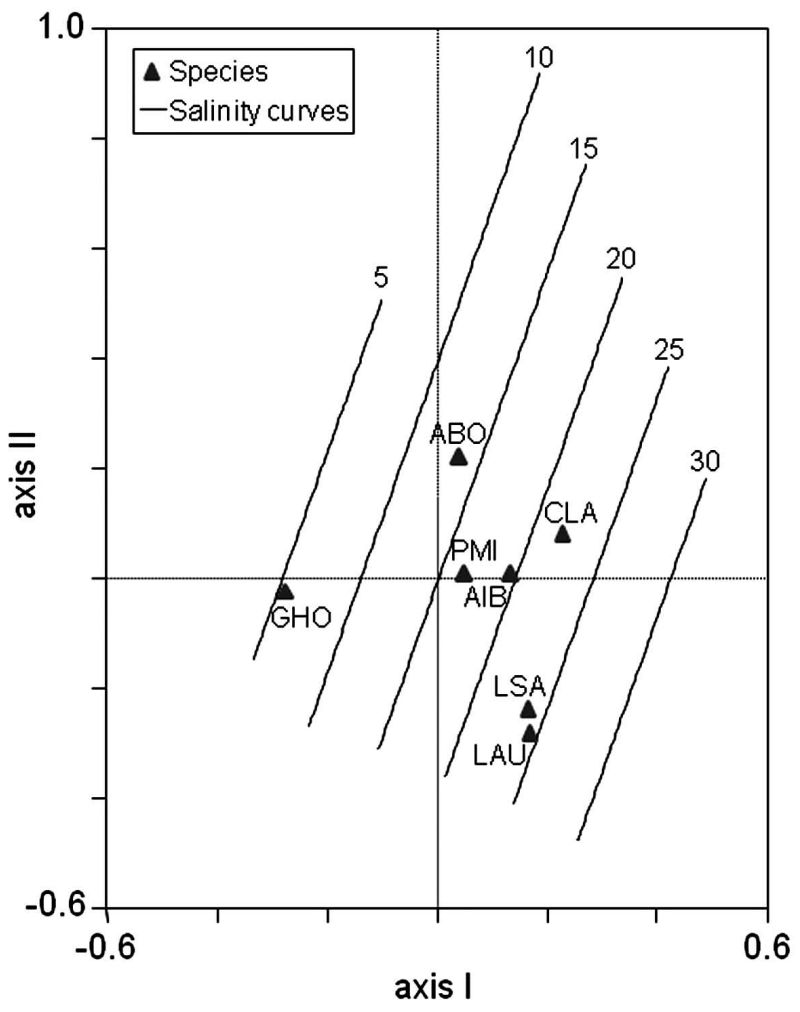

FIG. 5. - Species attribute plot showing salinity curves and the species preferences. Species abbreviations: ABO (Atherina boyeri), AIB (Aphanius iberus), CLA (Chelon labrosus), GHO (Gambusia holbrooki), LAU (Liza aurata), LSA (Liza saliens) and PMI (Pomatoschistus microps).

results contrasted with previous studies, which reported higher $\mathrm{pH}$ values in March (De Sostoa and De Sostoa 1985, Comín et al. 1987). These differences could be explained by the different management applied at each time, as the previous studies were carried out before the construction of the bypass canals (Forés et al. 2002). Furthermore, in addition to inverting the hydrological pattern, the continuous freshwater supplies tended to reduce the differences between the lagoons in September, whereas in March the differences between the lagoons were increased due to the cessation of the freshwater flow. Although the continuous freshwater inputs acted as a homogenizing agent, some differences still found between the lagoons within the same period could be attributed to a different water management scheme in each lagoon. This was the case of the Tancada lagoon, receiving the least freshwater inputs, and the Clot lagoon, receiving the greatest freshwater inputs. Therefore, these differences in freshwater inputs, in addition to the proximity to the sea, might explain the extreme differences in salinity values found between the Tancada and Clot lagoons.

The freshwater inputs in the lagoons are a mixture of drainage water from the rice fields and irrigating water from the Ebro River. During its entire course, the River Ebro collects nutrients from all the agricultural activities carried out in the basin (Mañosa et al. 2001). Furthermore, though rice fields are known to act 
as ecological filters, the drainage water still contains a high amount of nutrients (Forés and Comín 1992). This fact might explain the negative correlation between nutrient loading and salinity that is common in coastal systems affected by agriculture activities (Chapelle et al. 2000, Lucena et al. 2002, Pérez-Ruzafa et al. 2005a). Moreover, this freshwater input could promote turbulence, favouring the internal recycling process in the lagoons, as has been suggested for phosphate and ammonium (Chapelle et al. 2000, Orfanidis et al. 2005, Badosa et al. 2007).

The amount of freshwater/marine inputs has been pointed out as the key factor in determining the fish assemblages in an ecosystem (Gordo and Cabral 2001, Mariani 2001). Therefore, any change that could modify the natural inputs of freshwater/marine water (such as the artificialization of the hydrological cycle) would consequently modify the existing fish assemblage. Fish assemblages of Mediterranean coastal lagoons with a climate-dependent hydrology (i.e. where climatic variation such as rain and floods is the only source of freshwater inputs), have been reported to be characterized by marine and brackish species with the dominance of the families Sparidae, Mugilidae, Gobiidae, Atherinidae, Soleidae, Sygnathidae and Blennidae (Pérez-Ruzafa et al. 2006, Maci and Basset 2009, Verdiell-Cubedo 2009). On the other hand, fish assemblages of coastal lagoons with artificial freshwater supplies, such as the Vaccarès lagoon (France; Poizat et al. 2004) and the Albufera lagoon (Spain; Blanco et al. 2003, Blanco and Romo 2006), have families typical of freshwater environments, in addition to the aforementioned brackish and marine species. Our results suggest that the hydrological alteration of the cycle might be the responsible for the current fish community in the Ebro Delta coastal lagoons composed by brackish and marine families such as Gobidae, Mugilidae and Atherinidae and by freshwater species belonging to the families Cyprinidae and Poecilidae (Blanco et al. 2003, Poizat et al. 2004, Blanco and Romo 2006). Moreover, the introduction of the freshwater species (mostly the introduced Gambusia holbrooki) in these lagoons (Doadrio 2001) led to an alteration of the native species assemblage. The effect of the altered hydrological pattern on the proportion of native to introduced species was correlated with the management carried out in each lagoon, i.e. the higher proportion of native species found in the Tancada lagoon, even in the fresher period (September), reflects a lower perturbation of the fish community by the water management. In summary, in agreement with other studies on coastal ecosystems suffering from hydrological alterations (Flower 2001, Gordo and Cabral 2001, Poizat et al. 2004, Pérez-Ruzafa et al.2005b, Badosa et al. 2007, Cañedo-Argüelles et al. 2012), our data confirm that the small-fish community composition of the Ebro Delta coastal lagoons was affected by the altered hydrological pattern.

The hydrological alteration was also responsible for structuring the small-bodied fish community through salinity. The alternation of a freshwater input period with a non-input period creates a wide salinity range in the coastal lagoons that fish have to cope with. Fish have the capacity to keep their plasma osmotic concentration constant through osmoregulation (Rigal et al. 2008). However, this capacity differs between species, some being more or less tolerant to salinity variations (Blaber 1997, Marshall and Elliott 1998, Rigal et al. 2008). The abrupt decrease in abundance of the freshwater species Gambusia holbrooki with increasing salinities was probably due to the fact that its upper salinity tolerance is 25 (Nordlie and Mirandi 1996). This salinity tolerance could also explain its absence in March in Tancada lagoon, where the average salinity rose to 30. Moreover, a peak of abundance of the endangered Aphanius iberus was observed with the decrease of the invasive $G$. holbrooki. This finding could be attributed to the interaction of these two species, as some recent studies have pointed out. While some authors suggested that a sharp decrease in A. iberus in the presence of the G. holbrooki occurs not only because of the salinity preferences but also because G.holbrooki is more competitive due to its higher foraging ability, especially when it outnumbers the native species (Caiola and De Sostoa 2005), Rincón et al. (2002) hypothesized a possible predation of $G$. holbrooki on A. iberus juveniles. In whatever circumstances, our observed higher presence of the endangered $A$. iberus species in more saline habitats seems to be a response aimed at avoiding competition with the invasive G. holbrooki (Doadrio 2001, Rincón et al. 2002, Caiola and De Sostoa 2005).

The high osmoregulation capacity of Pomatoschistus microps (Rigal et al. 2008) was probably the reason for its presence in all three lagoons in both periods. Although this species shows a tolerance to a wide salinity range, a peak of abundance was found around 30, thus suggesting a higher preference for euhaline environments. Although Atherina boyeri was also found in all lagoons and periods, this species was not selected in the GAM analysis procedure due to a lack of response of its CPUE to the salinity gradient. A possible hypothesis to explain this fact could be that $A$. boyeri is the only small-bodied fish from the Ebro Delta coastal lagoons that is a target species (Rodríguez-Climent et al. 2012). The period of higher salinity coincides with the professional fishing season (from October to March). Therefore, the expected increase in the abundance of this species during the period of higher salinity is offset by the effect of fishery. Although members of the Mugilidae family spawn at sea (Kottelat and Freyhof 2007, Cardona et al. 2008), during their juvenile stages they enter coastal lagoons looking for a protected area with abundant food that will provide all the favourable conditions for their development (Verdiell-Cubedo 2009). In these habitats, salinity has been pointed out to be a key factor in determining the distribution pattern of young mugilids (Lasserre and Gallis 1975, Cardona 2006, Mićković et al. 2010). The low osmoregulation capacity of the juveniles of Liza saliens and Liza au- 
rata, together with their optimization of growth at high salinity levels (Cardona 2006, 2008), might explain their distribution in the present study, in which they were absent in freshwater areas and showed a preference for high salinity areas. The low abundance of Chelon labrosus in September was in accordance with its reduced osmoregulation capacity in freshwaters, where the species is not able to survive for more than a few months (Lasserre and Gallis 1975). Furthermore, the presence of C. labrosus in sites closest to the sea supported the hypothesis that marine connectivity plays an important role in the abundance of this species (Cardona et al. 2008). Although there is no doubt about the role played by salinity in the distribution patterns of the family, some authors have hypothesized that the high trophic overlap found among young mugilids determines their survival in low resources conditions (Gisbert et al. 1996). Thus, the dominance of $L$. saliens over L. aurata (the only other species with a preference for high salinity ranges) found in our study could be explained by a possible trophic competition (Gisbert et al. 1995, 1996, Cardona et al. 2008).

\section{CONCLUSIONS}

The present study is the first research approach describing the impact of the hydrological alteration on the fish assemblages of the Ebro Delta lagoons. It can be concluded that water management practices provoking hydrological alterations have a direct impact on the structure and dynamics of the coastal lagoons' fish assemblages. The current water management scheme developed in the Ebro Delta Natural Park is favoring the introduced species in detriment of the native ones. Of special mention was the inverse abundance trends found between the endangered Aphanius iberus and the invasive Gambusia holbrooki. This finding not only evidences two opposite salinity preferences but also corroborates previous studies that demonstrate that the invasive species affects the native one negatively. In addition, the different water management applied to each lagoon allowed us to conclude that the best management scheme regarding the fish assemblages was the one undertaken in the Tancada lagoon, characterized by less freshwater inputs during the rice cultivation period (May-December). Moreover, with salinities higher than 15-20 throughout the year, a fish community with a dominance of native species important for both commercial and conservation purposes is assured. This should be set as a key criterion in future water management schemes of the Ebro Delta coastal lagoons.

\section{ACKNOWLEDGEMENTS}

The authors wish to thank Carles Alcaraz, Lluís Jornet, Gloria Muñoz, David Mateu, Alfonso Nebra, Mireia San Lorenzo and Rosa Valmaña for their help in the field work and laboratory procedures. Financial support was provided by the INIA (Instituto Nacional de Investigación y Tecnología Agraria y Alimentaria) and FEDER with the project RTA 2009-00048-00-00.

\section{REFERENCES}

Alcaraz C., Caiola N., Ibánez C. 2011. Bioaccumulation of pollutants in the zebra mussel from hazardous industrial waste and evaluation of spatial distribution using GAMs. Sci. Total Environ. 409: 898-904.

Badosa A., Boix D., Brucet S., López-Flores R., Quintana X.D. 2007. Short-term effects of changes in water management on the limnological characteristics and zooplankton of a eutrophic Mediterranean coastal lagoon (NE Iberian Peninsula). Mar. Pollut. Bull. 54: 1273-1284.

Barnes R.S.K. 1980. Coastal Lagoons. Cambridge Univ. Press, 106 pp.

Blaber S.J.M. 1997. Fish and fisheries of tropical estuaries. Fish and Fisheries Ser. 22. Chapman and Hall, Cornwall, 367 pp.

Blanco S., Romo S., Villena M.-J., Martínez S. 2003. Fish communities and food web interactions in some shallow Mediterranean lakes. Hydrobiologia 506-509: 473-480.

Blanco S., Romo S. 2006. Ichthyofauna of Lake Albufera of Valencia (Spain): Past and present status. Bol. R. Soc. Esp. Hist. Nat. Biol. 101: 45-56.

Brazner J.C., Tanner D.K., Jensen D.A., Lemke A. 1998. Relative Abundance and Distribution of Ruffe (Gymnocephalus cern$u u s$ ) in a Lake Superior Coastal Wetland Fish Assemblage. J. Gt. Lakes Res. 24: 293-303.

Brehmer P., Chi T., Laugier T., Galgani F., Laloë F., Darnaude A., Fiandrino A., Mouillot D. 2011. Field investigations and multiindicators for shallow water lagoon management: perspective for societal benefit. Aquat. Conserv. 21: 728-742.

Caiola N., Vargas M.J., Sostoa A. 2001a. Feeding ecology of the endangered Valencia toothcarp, Valencia hispanica (Actinopterygii: Valenciidae). Hydrobiologia 448: 97-105.

Caiola N., Vargas M.J., Sostoa A. 2001b. Life history pattern of the endangered Valencia toothcarp, Valencia hispanica (Actinopterygii: Valenciidae) and its implications for conservation. Arch. Hydrobiol. 150: 473-489.

Caiola N., De Sostoa A. 2005. Possible reasons for the decline of two native toothcarps in the Iberian Peninsula: evidence of competition with the introduced Eastern mosquitofish. J. Appl. Ichthyol. 21: 358-363.

Cañedo-Argüelles M., Boix D., Sánchez-Millaruelo N., Sala J., Caiola N., Nebra A., Rieradevall M. 2012. A rapid bioassessment tool for the evaluation of the water quality of transitional waters. Est. Coast. Shelf Sci. 111: 129-138.

Cardona L. 2006. Habitat selection by grey mullets (Osteichthyes: Mugilidae) in Mediterranean estuaries: the role of salinity. Sci. Mar. 70: 443-455.

Cardona L., Hereu B., Torras X. 2008. Juveniles bottlenecks and salinity shape grey mullet assemblages in Mediterranean. Est. Coast. Mar. Sci. 77: 623-632.

Chapelle A., Ménesguen A., Deslous-Paoli J.M., Souchu P., Mazouni N., Vaquer A., Bertrand M. 2000. Modelling nitrogen, primary production and oxygen in a Mediterranean lagoon. Impact of oysters farming and inputs from the watershed. Ecol. Model. 127: 161-181.

Clifford B.R., Taylor A.T. 2008. SPSS 15.0 Supplement for: Biostatistics for the Health Sciences.

Cloern J.E. 2001. Our evolving conceptual model of the coastal eutrophication Problem. Mar. Ecol. Prog. Ser. 210: 223-253.

Comín F.A., Menéndez M., Forés E. 1987. Salinidad y nutrientes en las lagunas costeras del Delta del Ebro. Limnetica 3: 1-8.

Day J.W., Psuty N.P., Pérez B.C. 2000. The role of pulsing events in the functioning of coastal barriers and wetlands: Implications for human impact, management and the response to sea level rise. Proc. Meeting on Concepts and Controversies in Tidal Marsh Ecology.

Day J.W., Maltby E., Ibáñez C. 2006. River basin management and delta sustainability: A commentary on the Ebro Delta and the Spanish National Hydrological Plan. Ecol. Engin. 26: 85-99.

De Sostoa A., De Sostoa F.J. 1985. The fish communities of the Ebro Delta (Northeast Spain): a model of Mediterranean estuarine ecosystem. In: Yáñez-Arancibia A. (ed.), Fish Community 
Ecology in Estuaries and Coastal Lagoons: Towards an Ecosystem Integration. DR(R) UNAM Press, pp. 79-126.

Doadrio I. 2001. Atlas y libro rojo de los peces continentales de España. Consejo Superior de Investigaciones Científicas (CSIC), 364 pp.

Forés E., Comín F.A. 1992. Ricefields, a limnological perspective. Limnetica 8: 101-109.

Forés E., Espanya A., Morales F. 2002. Regeneración de la laguna costera de la Encanyissada (Delta del Ebro). Una experiencia de biomanipulación. Ecosistemas 11(2).

Flower R.J. 2001. Change, Stress, Sustainability and Aquatic ecosystem Resilience In North African wetland lakes during the $20^{\text {th }}$ century: An introduction to integrated biodiversity studies with the CASSARINA project. Aquat. Ecol. 35: 261-280.

Fredberg J., Smith B., Thwaites L., Conallin A., Fleer D. 2009. Monitoring temporal changes in the species composition and lateral movement patterns of small-bodied fishes within the inlet and outlet creeks to Banrock Station wetland. SARDI Publication No. F2009/000104-1, SRADI Research Report Series No. 337. Prepared by the South Australian Research and Development Institute (Aquatic Sciences), Adelaide, $18 \mathrm{pp}$.

Gisbert E., Cardona L., Castelló F. 1995. Competition between mullet fry. J. Fish. Biol. 47: 414-420.

Gisbert E., Cardona L., Castello F. 1996. Resource portioning among planktivorous fish larvae and fry in a Mediterranean coastal lagoon. Est. Coast. Mar. Sci. 43: 723-735.

Gordo L.S., Cabral H.N. 2001. The fish assemblage structure of a hydrologically altered coastal lagoon: the Obidos lagoon (Portugal). Hydrobiologia 459: 125-133.

Hastie T.J., Tibshirani R.J. 1986. Generalized Additive Models. Stat. Sci. 3: 297-318.

Ibáñez C., Alcaraz C., Caiola N., Rovira A., Trobajo R., Alonso M., Duran C., Jiménez P.J., Munné A., Prat N. 2012a. Regime shift from phytoplankton to macrophyte dominance in a large river: top-down versus bottom-up effects. Sci. Total Environ. 416: $314-22$

Ibáñez C., Caiola N., Rovira A., Real M. 2012b. Monitoring the effects of floods on submerged macrophytes in a large river. Sci. Total Environ. 440: 132-139.

Kottelat M., Freyhof J. 2007. Handbook of European Freshwater Fishes. Berlin, Germany: Kottelat, Cornol, Switzerland and Freyhof, $646 \mathrm{pp}$.

Koroleff F. 1977. Simultaneous persulphate oxidation of phosphorous and nitrogen compounds in water. In: Grasshoff K. (ed.), Report of Baltic Intercalibration Workshop. Annex. Interim Commission for the Protection of the Environment of the Baltic Sea, pp. 52-53.

Lasserre P., Gallis J-L. 1975. Osmoregulation and differential penetration of two grey mullets, Chelon labrosus (Risso) and Liza ramada (Risso) in estuarine fish ponds. Aquaculture 5: 323-344.

Lepš J., Śmilauer P. 2003. Multivariate analysis of ecological data using CANOCO, Cambridge Univ. Press.

Lucena JR., Hutado J., Comín F.A. 2002. Nutrients related to the hydrologic regime in the coastal lagoons of Viladecans (NE Spain). Hydrobiologia. 475: 413-422.

Maci S., Basset A. 2009. Composition, structural characteristics and temporal patterns of fish assemblages in non-tidal Mediterranean lagoons: A case study. Est. Coast. Shelf Sci. 83: 602-612.

Mañosa S., Mateo R., Guitart R. 2001. A review of the effects of agricultural and industrial contamination on the Ebro delta biota and wildlife. Environ. Monit. Assess. 71: 187-205.

Mariani S. 2001. Can spatial distribution of ichthyofauna describe marine influence on coastal lagoons? A central Mediterranean case study. Est. Coast. Mar. Sci. 52: 261-267.

Marshall S., Elliott M. 1998. Environmental influences on the fish assemblage of the Humber estuary, UK. Est. Coast. Mar. Sci. 46: $175-184$

Mićković B., Nikćević M., Hegediš A., Regner S., Gačić Z., KrpoĆetković J. 2010. Mullet fry (Mugilidae) in coastal waters of Montenegro, their spatial distribution and migration phenology. Arch. Biol. Sci. 62: 107-114.

Nebra A., Caiola N., Ibáñez C. 2011. Community structure of benthic macroinvertebrates inhabiting a highly stratified Mediterranean estuary. Sci. Mar. 75: 577-584.

Nordlie FG., Mirandi A. 1996. Salinity relationships in a freshwater population of eastern mosquitofish. J. Fish. Biol. 49: 1226-1232.

Oertli B., Biggs J., Céréghino R., Grillas P., Joly P., Lachavanne J.B. 2005. Conservation and monitoring of pond biodiversity: intro- duction. Aquat. Conserv.: Mar. Freshw. Ecosyst. 15: 535-540.

Orfanidis S., Stamatis N., Ragias V., Schramm W. 2005. Eutrophication patterns in an eastern Mediterranean coastal lagoon: Vassova, Delta Nestos, Macedonia, Greece. Medit. Mar. Sci. 6/2: 17-30.

Pampoulie C., Chauvelon P., Rosecchi E., Bouchereau J.L., Crivelli A.J. 2001. Environmental factors influencing the gobiid assemblage of a Mediterranean Lagoon: Empirical evidence from a long-term study. Hydrobiologia 445: 175-181.

Pérez-Ruzafa A., Marcos-Diego C., Ros J.D. 1991. Environmental and biological changes related to recent human activities in the Mar Menor (SE of Spain). Mar. Pollut. Bull. 23: 747-751.

Pérez-Ruzafa A., Quispe-Becerra J.I., García-Charton J.A., Marcos C. 2004. Composition, structure and distribution of the ichthyoplankton in a Mediterranean coastal lagoon. J. Fish. Biol. 64: 202-218.

Pérez-Ruzafa A., Fernández A.I., Marcos C., Gilabert J., Quispe J.I., García-Charton J.A. 2005a. Spatial and temporal variations of hydrological conditions, nutrients and chlorophyll $a$ in a Mediterranean coastal lagoon (Mar Menor, Spain). Hydrobiologia 550: 11-27.

Pérez-Ruzafa A., Marcos C., Gilabert J. 2005b. The ecology of the Mar Menor coastal lagoon: A fast changing ecosystem under human pressure. In: Gönenç I.E and Wolfin J.P. (eds), Coastal lagoons. Ecosystem processes and modeling for sustainable use and development. CRC Press Boca Raton, 392-422 pp.

Pérez-Ruzafa A., García-Charton J.A., Barcala E., Marcos C. 2006. Changes in benthic fish assemblages as a consequence of coastal works in a coastal lagoon: The Mar Menor (Spain, Western Mediterranean). Mar. Pollut. Bull. 53: 107-120.

Poizat G., Rosecchi E., Chauvelon P., Contournet P., Crivelli A.J. 2004. Long-term fish and macro-crustacean community variation in a Mediterranean lagoon. Est. Coast. Shelf Sci. 59: 615-624.

Poole W.R., Rogan G., Mullen A. 2007. Investigation into the impact of fyke nets in otter populations in Ireland. Irish Wildlife Manuals No.27. National Parks and Wildlife Service, Department of Environment, Heritage and Local Government, Dublin, Ireland.

Quinn G.P., Keough M.J. 2002. Experimental design and data analysis for biologists. Cambridge University Press, Cambridge, $537 \mathrm{pp}$.

Ribeiro J., Bentes L., Coelho R., Gonçalves J.M.S., Lino P.G., Monteiro P., Erzini K. 2006. Seasonal, tidal and diurnal changes in fish assemblages in the Ria Formosa lagoon (Portugal). Est. Coast. Shelf Sci. 67: 461-474.

Rigal F., Chevalier T., Lorin-Nebel C., Charmantier G., Tomasini J.A., Aujoulat F., Berrebi P. 2008. Osmoregulation as a potential factor for the differential distribution of two cryptic gobiid species, Pomatoschistus microps and P.marmoratus in French Mediterranean lagoons. Sci. Mar. 72: 469-476.

Rincón P.A., Correas A.M., Morcillo F., Risueño P., Lobón-Cerviá J. 2002. Interaction between the introduced eastern mosquitofish and two autochthonous Spanish toothcarps. J. Fish. Biol. 61: 1560-1585.

Rodríguez-Climent S., Alcaraz C., Caiola N., Ibáñez C., Nebra A., Muñoz-Camarillo G., Casals F., Vinyoles D., De Sostoa A. 2012. Gillnet selectivity in the Ebro Delta coastal lagoons and its implication for the fishery management of the sand smelt, Atherina boyeri (Actinopterygii: Atherinidae). Est. Coast. Shelf Sci. 114: 41-49.

Uzarski D.G., Burton T.M., Cooper M.J., Ingram J.W., Timmermans S.T.A. 2005. Fish habitat use within and across wetland classes in coastal wetlands of the five Great Lakes: development of a fish-based index of biotic integrity. J. Gt. Lakes Res. 31: 171-187.

Verdiell-Cubedo D. 2009. Ictiofauna de las zonas someras litorales del Mar Menor (SE, Península Ibérica): Parámetros de su biología y relaciones con el hábitat. $\mathrm{PhD}$ thesis, Univ. Murcia, $165 \mathrm{pp}$.

Wedderburn S.D., Hammer M.P., Bice C.M. 2012. Shifts in smallbodied fish assemblages resulting from drought-induced water level recession in terminating lakes of the Murray-Darling Basin, Australia. Hydrobiologia 691: 35-46.

Scient. ed.: V.D. Valavanis.

Received July 11, 2012. Accepted January 18, 2013.

Published online February 26, 2013. 